Available online at website : http://e-journal.adpgmiindonesia.com/index.php/jmie JMIE: Journal of Madrasah Ibtidaiyah Education, 3(2), 2019, 219-232

\title{
PENGARUH MEDIA KOMIK UNTUK MENINGKATKAN KEMAMPUAN KONEKSI MATEMATIS SISWA SEKOLAH DASAR
}

\author{
Naifatul Musyarrofah"1), Fatkhul Arifin ${ }^{2)}$, Fery Muhamad Firdaus ${ }^{3)}$ \\ Universitas Islam Negeri Syarif Hidayatullah Jakarta ${ }^{1,2}$ \\ Universitas Negeri Yogyakarta3) \\ Email: naifatul.musyarrofah15@mhs.uinjkt.ac.id ${ }^{1}$,fatkhul_arf@uinjkt.ac.id²), \\ fery.firdaus@uny.ac.id $\left.{ }^{3}\right)$ \\ Naskah diterima : 29 Agustus 2019, direvisi : 29 September 2019, disetujui : 1 Oktober 2019
}

\begin{abstract}
Abstrak
Penelitian ini bertujuan untuk mengetahui pengaruh penggunaan media komik terhadap kemampuan koneksi matematis siswa kelas V SDN Lebak Wangi pada materi kecepatan dan debit. Penelitian ini dilaksanakan pada tahun ajaran 2019/2020. Metode yang digunakan dalam penelitian ini adalah metode kuasi eksperimen (quasi eksperimental) dengan desain penelitian Nonequivalent Posttest-Only Group Design. Sampel dalam penelitian ini terdiri atas kelas eksperimen yang berjumlah 33 siswa dan kelas kontrol yang berjumlah 33 siswa. Hasil penelitian menunjukkan bahwa siswa yang diajarkan menggunakan media komik memperoleh rata-rata kemampuan koneksi matematis siswa lebih tinggi dibandingkan dengan nilai rata-rata kemampuan koneksi matematis siswa yang diajarkan tanpa menggunakan media komik. Hal ini dapat dilihat dari hasil uji t-test posttest kelas eksperimen dan kelas kontrol sebesar 0,004 dengan taraf signifikansi 0,05 . Dengan demikian, ini menunjukkan bahwa terdapat pengaruh pada penggunaan media komik untuk meningkatkan kemampuan koneksi matematis pada siswa sekolah dasar.
\end{abstract}

Kata Kunci: Media Komik, Kemampuan Koneksi Matematis, Kecepatan dan Debit.

Pengutipan: Naifatul Musyarofah, dkk. (2019). Pengarub Media Komik untuk Meningkatkan Kemampuan Koneksi Matematis Siswa Sekolah Dasar. JMIE: Journal of Madrasah Ibtidaiyah Education,3(2), 2019, 219-232. jmie.v3i2.135.

Permalink/DOI: http://dx.doi.org/10.32934/jmie.v3i2.135 


\section{PENDAHULUAN}

Pendidikan merupakan suatu hal yang sangat penting dan tidak dapat dipisahkan dari kehidupan seseorang baik dari keluarga, masyarakat, dan bangsa. Salah satu faktor kemajuan suatu bangsa ditentukan oleh tingkat keberhasilan pendidikan dalam suatu bangsa. Hal ini sesuai dengan tujuan pendidikan nasional indonesia yang terdapat pada Undang-undang No. 20 Tahun 2003 tentang sistem pendidikan nasional menyatakan bahwa, pendidikan nasional berfungsi mengembangan kemampuan dan membentuk watak serta peradaban bangsa, bertujuan untuk mengembangkan potensi peserta didik agar menjadi manusia yang beriman dan bertakwa kepada tuhan yang maha esa, berakhlak mulia, sehar, berilmu, cakap, kreatif, mandiri, dan menjadi warga negara yang demokrasi serta bertanggung jawab.

Tingkat pendidikan di Indonesia terbagi menjadi beberapa jenjang pendidikan yang harus ditempuh oleh setiap warga negara Indonesia. Pada jenjang pendidikan formal terdiri dari pendidikan dasar, pendidikan menengah, dan pendidikan tinggi. Pendidikan dasar terdiri dari beberapa jenjang yang diatur dalam Peraturan Pemerintah No. 47 Tahun 2008 tentang wajib belajar, yaitu berbentuk Sekolah Dasar (SD) dan Madrasah Ibtidaiyah (MI) atau bentuk lain yang sederajat, serta Sekolah Menengah Pertama (SMP) dan Madrasah Tsanawiyah (MTS) atau bentuk lain yang sederajat.

Mulai dari jenjang pendidikan dasar, siswa harus mulai diberi pengetahuan dasar serta kemampuan dasar yang perlu dikembangkan sejak diri agar dapat membantu siswa dalam menyelesaikan masalah yang dihadapi pada kehiduan sehari-hari. Salah satu pelajaran yang harus diterima oleh siswa sejar jenjang pendidikan dasar adalah matematika. Matematika adalah salah satu mata pelajaran yang diajarkan sejak pendidikan dasar hingga tingkat pendidikan tinggi. Hal ini menunjukkan bahwa matematika merupakan komponen penting dalam lingkungan pendidikan dan pengembangan teknologi saat ini (Arifin \& Herman, 2017). Dengan demikian matematika merupaka salah satu ilmu yang selalu berkembang mengikuti perkembangan zaman serta banyak digunakan untuk membantu manusia dalam menangani masalah dalam kehidupan sehari-hari.

Menurut NCTM (National Council of Teacher od Mathematics), menetapkan lima standar kemampuan matematis yang harus dimiliki siswa, yaitu pemecahan masalah (problem solving), kemampuan komunikasi (communication), kemampaun koneksi (connection), kemampuan penalaran (reasoning), dan kemampuan representasi (representation). Salah satu kemampuan matematis siswa yang perlu dimiliki dan dikembangkan siswa sejak dini adalah kemampuan koneksi matematis. Berdasarkan pada kurikulum 2013 pun disebutkan bahwa setiap kegiatan pembelajaran harus ditekankan untuk melatih siswa untuk menghubungkan materi yang sudah 
dipelajari di sekolah dengan menerapkan dalam kehidupan sehari-hari. Dengan demikian maka siswa dapat mengembangkan kemampuan koneksi matematis dan mempermudah siswa dalam memahami setiap konsep matematika yang diajarkan oleh guru (Ramdhani, 2016).

Menurut Coxford, kemampuan koneksi matematis adalah kemampuan untuk menghubungkan pengetahuan yang dimiliki, baik secara konseptual maupun prosedural, serta memapu menggunakan matematika pada topik lain, menggunakan matematika dalam kehidupan sehari-hari, dan mampu mengetahui koneksi yang dimiliki oleh setiap konsep dalam matematika (Siagian, 2016). Oleh karena itu, kemampuan koneksi matematis siswa sangatlah penting dalam pembelajaran matematika. Jika siswa hanya memahami konsep dari matematika saja, tanpa mengetahui keterkaitannya dengan materi matematika lainnya atau dengan kehidupan, maka siswa akan sulit untuk menggunakan materi yang telah ia pelajari dalam kehidupan sehari-hari.

Suatu pembelajaran akan lebih bermakna jika pendidikan berlandaskan pada empat pilar utama, yaitu peserta didik mengetahui sesuatu (learning to know), belajar melakukan (learning to do), belajar menjiwai (learning to be), belajar bagaimana harusnya belajar (learning to learn), serta belajar bersosialisasi (learning to live together) (Rahmita, 2016). Dengan berlandaskan empat pilar tersebut, maka pembelajaran tidak sekedar siswa memahami suatu konsep matematika, tetapi pembelajaran dilakukan dengan suatu kegiatan yang mampu membuat pembelajaran jadi lebih bermakna, sehingga dapat meningkatkan prestasi siswa dalam bidang matematika, selain itu siswa dapat mengkoneksikan dan mengkomunikasikan metamtika dalam menyelesaikan permasalahan yang dihadapi siswa dalam kehidupan sheari-hari.

Berdasarkan hasil penelitian PISA (Programme for International Student Assessment) tahun 2015, Indonesia mengalami peningkatan posisi yaitu 6 peringkat ke atas bila dibandingkan posisi peringkat kedua dari bawah pada tahun 2012 dari 72 negara. Dalam kompetensi matematika meningkat dari 375 poin pada tahun 2012 menjadi 386 pada tahun 2015. Berdasarkan hasil tersebut Indonesia menunjukan kenaikan pencapaian pendidikan yang signifikan yaitu 22,1 poin, meskipun masih rendah jika dibandingkan dengan rata-rata OECD (organization for economic cooperation and development). Berdasarkan hasil penelitian tersebut, maka dapat disimpulkan bahwa kompetensi matematika siswa Indonesia masih tergolong rendah dibandingkan dengan kemampuan matematika yang diperoleh oleh beberapa negara lainnya.

Agar pembelajaran lebih bermakna dan dapat memotivasi siswa sehingga dapat meningkatkan minat belajar siswa, maka diperlukan guru yang kreatif dalam memiliki media, metode, serta pendekatan yang tepat, harus sesuai dengan materi dan kondisi siswa. Hamalik mengemukakan bahwa dengan pemakaian media pembelajaran dalam proses pembelajaran 
dapat membangkitkan minat belajar, motivasi dan menjadi stimulus dalam proses pembelajaran, serta menjadikan kegiatan pembelajaran lebih efektif dan efisien. Selain itu dapat meningkatkan pemahaman siswa dengan menyajikan data yang menarik sehingga siswa lebih mudah dalam menerima informasi yang disampaikan melalui media tersebut (Arsyad, 2004).

Media pembelajaran terbagi menjadi beberapa jenis, yaitu media berbasis audio, visual, dan audiovisual. Media berbasis visual merupakan media yang memegang peran sangat penting dalam keberhasilan suatu proses pembelajaran. Media visual dapat meningkatkan minat siswa dan dapat mengkoneksikan materi dalam pembelajaran dengan kehidupan sehari-hari. Agar menjadi efektig, media visual sebaiknya ditempatkan pada konteks yang bermakna dan harus terjadi interaksi antara siswa dengan media visual tersebut agar informasi dapat dipahami oleh siswa (Arsyad, 2004).

Gaya belajar siswa terbagi menjadi beberapa jenis, yaitu gaya belajar visual, audio, dan konestetik. Jenis media yang sangat mempengaruhi keberhasilan suatu proses pembelajaran, yaitu media visual, maka dapat disimpulkan bahwa sebagian besar siswa memiliki gaya belajar visual. Salah satu media visual yang dapat digunakan oleh guru adalah komik. Gambar dalam komik terdiri dari beberapa karakter gambar kartun yang disajikan dalam bentuk informasi yang menarik. Komik mempunyai sifat yang sederhana dalam penyajiannya, dan memiliki unsur cerita yang memuat informasi yang luas dengan penyajian yang menarik dan mudah dipahami oleh siswa (Munadi, 2008). Dengan menggunakan edia komik dalam pembelajaran, maka akan sangat membantu pembelajaran menjadi efektif dan efisien, serta menjadikan pembelajaran lebih menarik dan menyenangkan bagi siswa. Selain itu komik merupakan salah satu media visual yang cukup digemari oleh anak-anak.

Dalam hal ini, penulis mempunyai ide untuk membuat sebuah media komik yang akan disesuaikan dengan materi dan perkembangkan siswa sekolah dasar. Dengan penggunaan media komik diharapkan dapat meningkatkan kemampuan koneksi matematis siswa pada jenjang sekolah dasar.

\section{METODE}

Metode yang digunakan dalam penelitian ini adalah metode kuasi eksperimen (quasi experimental). Penelitian dilakukan pada dua kelas, yaitu kelas eksperimen, dan kelas kontrol. Pada kelas eksperimen pembelajaran matematika menggunakan media pembelajaran komik pada materi kecepatan dan debit, sedangkan pada kelas kontrol pembelajaran matematika tanpa menggunakan media pembelajaran komik pada materi kecepatan dan debit. Penelitian 
ini dilakukan untuk menguji adakah pengaruh penggunaan media pembelajaran komik terhadap kemampuan koneksi matematis siswa sekolah dasar.

Desain penelitian yang digunakan pada penelitian ini adalah The Nonequivalent PosttestOnly Group Design, dan populasi dalam penelitian ini adalah siswa-siswi SDN Lebak Wangi, dengan Sampel yang diambil sebanyak dua kelas, yaitu kelas V-A sebagai kelas kontrol dan kelas V-B sebagai kelas eksperimen. Masing-masing kelas terdapat 33 siswa.

\section{HASIL PENELITIAN}

Penyajian hasil data posttest dengan menggunakan aplikasi SPSS 22, dapat dilihat pada tabel dibawah ini:

Tabel 1. Deskripsi Data Posttest

\begin{tabular}{|r|r|r|}
\hline & Kelas_Eksperimen & Kelas_Kontrol \\
\hline $\mathrm{N} \quad$ Valid & 33 & 33 \\
Missing & 0 & 0 \\
Mean & 71,15 & 57,06 \\
Std. Error of & 3,756 & 2,860 \\
Mean & 77,00 & 53,00 \\
Median & 87 & 53 \\
Mode & 21,576 & 16,432 \\
Std. Deviation & 465,508 & 269,996 \\
Variance & 70 & 64 \\
Range & 30 & 23 \\
Minimum & 100 & 87 \\
Maximum & 2348 & 1883 \\
Sum &
\end{tabular}

Berdasarkan tabel diatas menunjukkan bahwa hasil posttest kelas eksperimen diperoleh data sebanyak 33 siswa dengan nilai rata-rata (mean) sebesar 71,15, nilai tengah sebesar (median) 77, nilai yang sering muncul (mode) sebesar 465,508, nilai tertinggi (maximum) sebesar 100, nilai terendah (minimum) sebesar 30, standar deviasi sebesar 21,576, varian sebesar 465,508, dan range sebesar 70 .

Sedangkan hasil posttest kelas kontrol diperoleh data sebanyak 33 siswa dengan nilai ratarata (mean) sebesar 57,06, nilai tengan (median) sebesar 53, nilai yang sering muncul (mode) sebesar 53, nilai tertinggi (maximum) sebesar 87, nilai terendah (minimum) sebesar 23, standar deviasi sebesar 16,432, variansi sebesar269,996, dan range sebesar 64. 
Uji normalitas posttest yang digunakan dalam peleitian ini, yaitu dengan bantuan program SPSS 22 dengan metode Kolmogorov-smirnov dengan syarat signifikansi probobalitas $>$ 0.05 .

Tabel 2. Hasil Uji Normalitas Posttest

\begin{tabular}{|c|r|r|r|}
\hline \multirow{2}{*}{} & \multicolumn{3}{|c|}{ Kolmogorov-Smirnova $^{\mathrm{a}}$} \\
\cline { 2 - 4 } & \multicolumn{1}{|c|}{ Statistic } & \multicolumn{1}{c|}{$\mathrm{df}$} & \multicolumn{1}{|c|}{ Sig. } \\
\hline Kelas_Eksperimen &, 145 & 33 &, 074 \\
Kelas_Kontrol &, 143 & 33 &, 084 \\
\hline
\end{tabular}

Berdasarkan tabel datas, dapat diketahui bahwa hasil posttest kelas eksperimen mendapatkan hasil signifikansi 0,074. Hal ini menunjukkan bahwa data tersebut berdistribusi normal karena signifikansinya 0,074 >0,05 dan hasil posttest kelas kontrol mendapatkan hasil signifikansi 0,084. Hal ini menunjukkan bahwa data tersebut berdistrbusi normal karena signifikansinya $0,084>0,05$.

Uji homogenitas posttest kelas eksperimen dan kelas kontrol, yakni dengan bantuan program SPSS One Way Anova. Dengan bantuan uji homogeneity of varance test pada one way anova, jika nilai signifikansi $>0,05$ maka dikatakan bahwa varian dari data atau kelompok populasi data terbukti sama (homogen), sedangkan jika nilai signifikansi $<0.05$ maka dikatakan bahwa varian dari data atau kelompok populasi daya terbukti tidak sama (tidak homogen).

Tabel 3. Hasil Uji Homogenitas Posttest Kelas Eksperimen dan Kelas Kontrol

\begin{tabular}{|c|c|c|c|}
\hline Levene Statistic & df1 & df2 & Sig. \\
\hline 2,604 & 1 & 64 & ,112 \\
\hline
\end{tabular}

Berdasarkan tabel tersebut dapat diketahui bahwa hasil posttest kelas eksperimen dan kelas kontrol signifikansinya 0,112. Hal ini dapat disimpulkan bahwa varian yang dimiliki oleh kedua kelas yakni sama (homogen), karena signifikansinya 0,112 >0,05.

Pengujian hipotesis posttest kelas eksperimen dan kelas kontrol pada penelitian ini dilakukan dengan analisis parametrik. Hal ini dikarenakan hasil data posttest kelas eksperimen da kelas kontrol berdistribusi normal. Oleh karena itu, penelitian ini menggunakan uji independent sample t-test dengan bantuan program SPSS 22.

Adapun kriteria pengujian hipotesis adalah jika signifikansi t-test $>0,05$ maka $\mathrm{H}_{0}$ diterima dan $\mathrm{H}_{1}$ ditolak, dan jika signifikansi t-test $<0,05$ maka $\mathrm{H}_{0}$ ditolak dan $\mathrm{H}_{1}$ diterima. 
Tabel 4. Hasil Uji T-Test Posttest

\begin{tabular}{|rc|r|r|r|}
\hline \multirow{2}{*}{} & & \multicolumn{3}{|c|}{ t-test for Equality of Means } \\
\cline { 3 - 5 } & & $\begin{array}{c}\text { Sig. (2- } \\
\text { tailed) }\end{array}$ & $\begin{array}{c}\text { Mean } \\
\text { Difference }\end{array}$ & $\begin{array}{c}\text { Std. Error } \\
\text { Difference }\end{array}$ \\
\hline Hasil_Posttest & Equal variances assumed &, 004 & 14,091 & 4,721 \\
\cline { 2 - 5 } & Equal variances not assumed &, 004 & 14,091 & 4,721 \\
\hline
\end{tabular}

Berdasarkan tabel diatas, diketahui bahwa hasil uji t-test posttest kelas eksperimen dan kontrol mendapatkan signifikansi 0,004 . Hal ini dapat disimpulkan bahwa $\mathrm{H}_{0}$ ditolak dan $\mathrm{H}_{1}$ diterima, artinya terdapat perbedaan yang signifikan antara hasil tes kemamuan koneksi matematis siswa kelas eksperimen dan kelas kontrol.

Berdasarkan penelitian yang telah dilakukan, peneliti menemukan bahwa terdapat pengaruh yang signifikan pada penggunaan media komik terhadap kemampuan koneksi matematis siswa di kelas V SDN Lebak Wangi. Hal ini dapat dilihata dari nilai rata-rata kelas eksperimen sebesar 71,15, sedangkan kelas kontrol sebesar 57,06.

Menurut NCTM (National Council of Teacher od Mathematics), menetapkan lima standar kemampuan matematis yang harus dimiliki siswa, yaitu pemecahan masalah (problem solving), kemampuan komunikasi (communication), kemampaun koneksi (connection), kemampuan penalaran (reasoning), dan kemampuan representasi (representation). Hal tersebut menegaskan bahwa kemampuan koneksi matematis merupakan salah satu standar kemampuan yang harus dimiliki dan ditingkatkna dalam proses pembelajaran. Oleh karena itu, penelitian ini berfokus untuk meneliti kemampuan koneksi matermatis siswa dengan menggunakan media komik pada materi kecepatan dan debit.

Selain itu Bruner mengemukakan bahwa agar proses pembelajar matematika lebih berhasil, maka siswa harus dilatih untuk melihat kaitan-kaitan dalam ide-ide matematika yang mereka pelajari, baik kaitan antara cabang matematika ataupun keterkaitan antar topik, konsep maupun dalil-dalil matematika, agar membuat siswa belajar lebih bermakna dan kebih mudah mencapai tujuan pembelajaran (Siagian, 2016). Berdasarkan pendapat Brunner, maka dapat disimpukan bahwa keberhasilan proses pembelajaran matematika sangat berpengaruh dengan kemampuan koneksi matematis siswa, karena dengan meningkatkan kemampuan koneksi matematis siswa dapat memandang matematika sebagai suatu kesatuan yang dapat dipelajari dengan mudah secara berkelanjutan dari materi sebelumnya menuju materi selanjutnya, dan 
siswa mampu melihat kebermanfaatan ilmu matematika dalam menyelesaikan permasalahan yang ditemui dalam kehidupan sehari-hari.

Menurut Hamalik, pemakain media pembelajaran dalam prose pembelajaran sangat bermanfaat untuk membangkitkan keinginan dan minat yang baru, membangkitkan motivasi dan rangsangan dalam belajar, dan dapat mempengaruhi psikologi siswa (Siagian, 2016). Dengan menggunakan media komik diharapkan dapat menciptakan suasana belajar yang menyenangkan, serta menjadi pembelajaran lebih efektif dan efisien yang dapat meningkatkan kemamuan koneksi matematis siswa.

Media berbasis visual sangat berperan penting dalam keberlangsungan proses pembelajaran, karena media visual memberikan hubungan antara isi materi pelajaran dengan dunia nyata. Agar menjadi efektif, media visual sebaiknya ditempatkan pada konteks yang bermakna dan siswa hrus berinteraksi dnegan media visual itu untuk meyakinkan terjadinya proses penerimaan pesan atau informasi (Siagian, 2016). Oleh karena itu peneliti memilih media visual dalam bentuk komik agar dapat menarik perhatian siswa sehingga dapat meningkatkan kemampuan koneksi matematis siswa. Beriku merupakan contoh yang dibuat oleh peneliti.
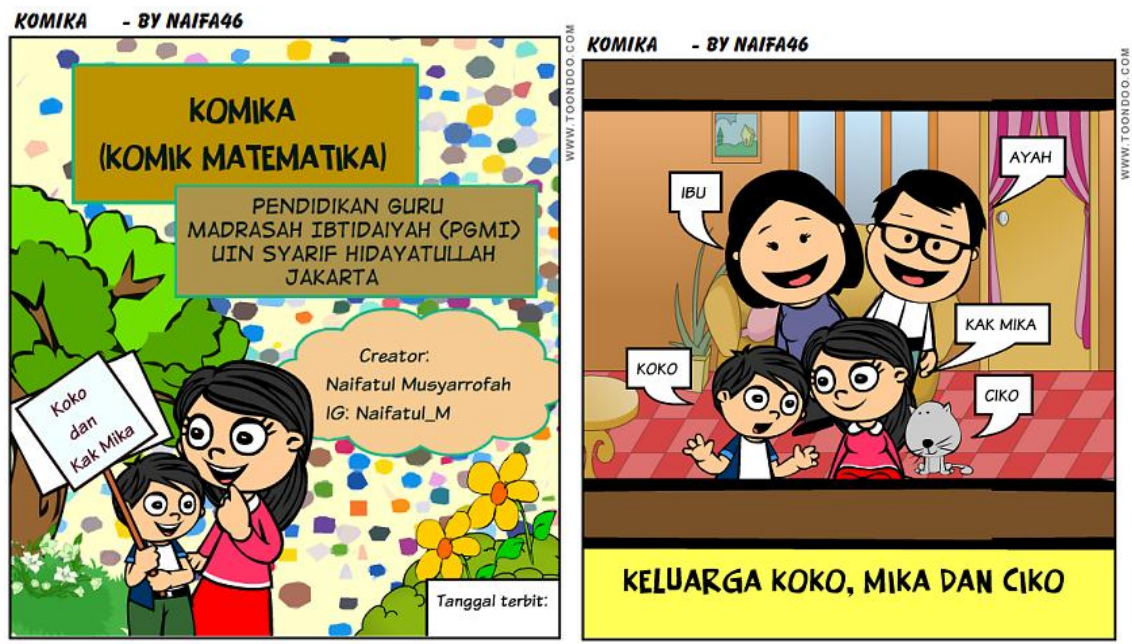

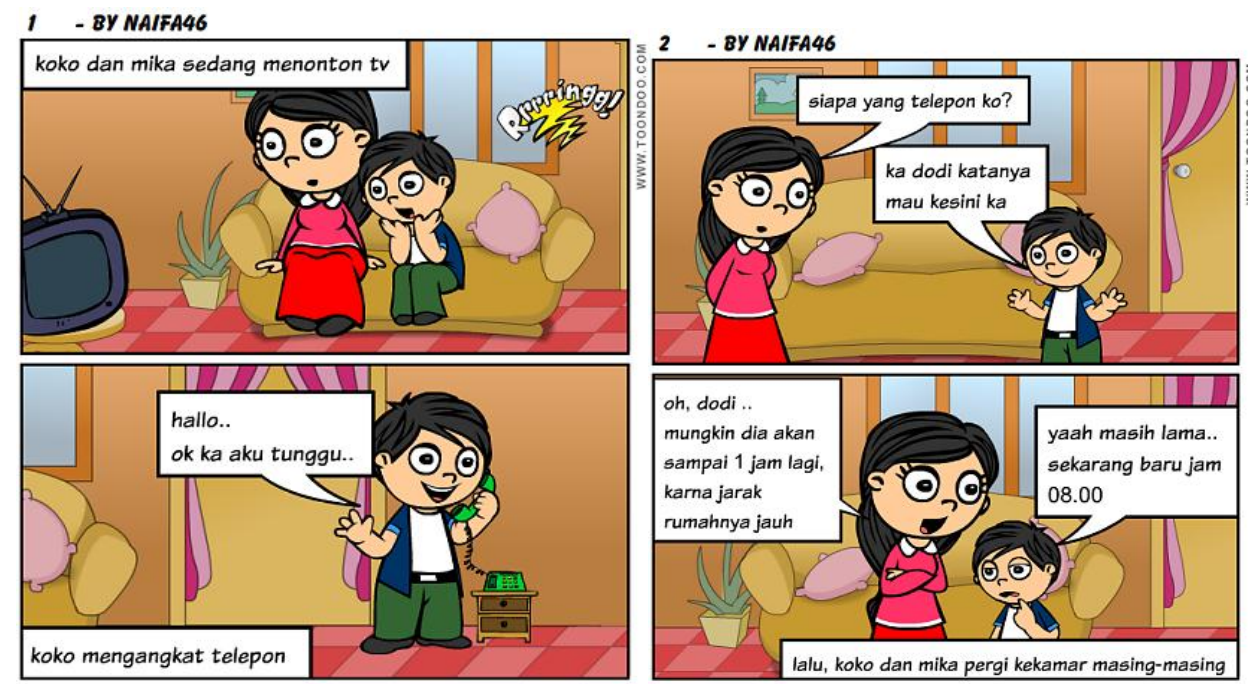

Gambar 1. Contoh Media Komik

Komik dapat dijadikan media pembelajaran, komik memiliki sifat dan penyajian yang sederhana, memiliki alur cerita yang menarik dengan mengandung pesan yang besar, serta dilengkapi dengan bahasa verbal yang dialogis (Munadi, 2008). Sehingga dengan menggunakan media komik dalam pembelajaran, maka akan mempermudah siswa menerima pesan atau informasi dengan cara yang lebih mudah dan menyenangkan dalam tampilan komik yang dapat dibaca oleh siswa.

Berdasarkan data diatas, maka dapat disimpulkan bahwa terdapat pengaruh pada penggunaan media komik untuk meningkatkan kemampuan koneksi matematis pada siswa sekolah dasar. Perbedaan rata-rata hasil tes koneksi matematis siswa kelas eksperimen dan kelas kontrol menunjukkan bahwa pembelajaran matematika pada materi kecepatan dan debit dengan menggunakan media komik lebih efektif dari pada pembelajaran tanpa menggunakan media komik. Hal ini didukung oleh hasil pengamatan langsung peneliti selama pembelajaran siswa lebih tertarik menggunakan media komik dan lebih mampu mengembangkan kemampuan koneksi matematis. Pada penelitian ini, lebih tingginya hasil tes koneksi matematis siswa yang menggunakna media komik dibuktikan oleh perbedaan nilai rata-rata dan diperkuat dengan hasil pengujian hipotesis. 


\section{PEMBAHASAN}

\section{Koneksi Matematis}

Dalam kamus besar bahasa Indonesia, koneksi artinya hubungan yang dapat memudahkan atau melancarkan segala urusan atau kegiatan, dan matematis artinya bersangkutan dengan matematika. Jadi suatu hubungan yang berkaitan dengan matematika disebut koneksi matematis. Menurut NCTM, koneksi matematis adalah suatu kemampuan untuk mengetahui, memnggunakan dan membuat hubungan antara ide-ide matematika, serta diluar ide-ide matematika untuk membangun pemahaman matematika (Mulyawati, 2017).

Sedangkan Brunner mengemukakam, bahwa dalam matematika setiap konsep atau ideide matematika terdapat keterkaitan satu sama lain, bukan hanya dari segi isi, namun juga dari rumus-rumus yang digunakan merupakan suatu rumus turunan dari rumus dari konsep atau ide matematika sebelumnya. Sehingga suatu materi merupakan prasyarat bagi materi lainnya, atau suatu konsep tertentu diperlukan untuk menjelaskan dan memahami konsep lainnya (Fajrani, 2017). Berdasarkan pemaparan diatas, maka dapat disimpulkan bahwa koneksi matematis adalah suatu kemampuan dalam menghubungkan matematika dengan konsep atau materi lain, baik dengan ilmu matematika itu sendiri, dengan ilmu diluar matematika, ataupun dengan kehidupan sehari-hari.

Teori yang mendukung kemampuan koneksi matematis adalah teori belajar Brunner. Menurut Brunner, belajar matematika adalah suatu proses belajar tentang konsep dan struktur matematika yang terdapat dalam materi yang dipelajari, serta menghubungkan setiap konsep dan struktur yang ada dalam matematika (Atridayani, 2017). Dengan memahami konsep dan struktur matematika, maka menjadikan matematika lebih mudah dipahami secara lebih komprehensif.

Selain itu menurut Brunner, terdapat empat teorema belajar dan mengajar, yaitu teorema konstruksi, teorema notasi,teorema kekontrasan atau variasi, dan teorema konektivitas. Dalam teorema konektivitas dinyatakan bahwa konsep tertentu harus dikaitkan dengan konsep-konsep lain yang relevan (Shadiq, 2011). Dengan demikian siswa mampu mempelajari matematika sebagai suatu kesatuan, bukan suatu materi yang berbeda. Sehingga memudahkan siswa untuk memahami hubungan antar konsep atau materi lainnya dan siswa mampu menghubungkannya kedalam permasalahan kehidupan sehari-hari.

Dalam kesempatan kali ini, peneliti mengadopsi indikator koneksi matematis yang dikemukakan oleh NCTM (2000) dikolaborasikan dengan materi ajar kecepatan dan debit, yaitu: 
a. Menggunakan hubungan di antara ide-ide matematika pada materi kecepatan dan debit

b. Menunjukkan ide matematik saling berhubungan dan membangun satu dengan yang lain untuk menghasilkan keterkaitan secara menyeluruh pada materi kecepatan dan debit

c. Menerapkan koneksi matematika pada materi kecepatan dan debit dalam konteks di kehidupan sehari-hari

\section{Komik Sebagai Media Pembelajaran}

Kata media berasal dari bahasa latin yaitu "Medius" yang artinya tengah, perantara, atau pengantar. Secara istilah dalam bahasa arab, media adalah pengantar atau perantara informasi atau pesan kepada penerima. Menurut Gerlach dan Ely, media adalah manusia, materi, kejadian yang dapat membangun suatu kondisi yang dapat membuat siswa memperoleh pengetahuan, keterampilan dan sikap (Arsyad, 2004). Salah satu media yang dapat dimanfaatkan oleh guru untuk menjadikan proses pembelajaran lebih bermakna dan menyenangkan, maka dapat menggunakan media komik. Media komik termasuk kedalam klasifikasi media visual yang dapat disesuaikan dengan materi yang akan diajarkan kepada siswa.

Komik berasal dari bahasa perancis yaitu "Comique" yang artinya lucu, atau dapat diartikan sebagai pelawak atau badut (Ulfah). Komik adalah suatu bentuk media visual yang dapat menyampaikan informasi secara populer dan mudah dipahami oleh siswa. Hal tersebut karena komik memadukan gambar dan tulisan yang dirangkai dalam alur cerita yang menarik, sehingga membuat informasi lebih mudah dimengerti. Keterangan tulisan dalam komik membuatnya lebih mudah dimengerti, dan alur certa yang menarik membuatnya lebih mudah untuk diikuti dan diingat (Waluyanto, 2005).

Berdasarkan pemaparan diatas maka dapat disimpulkan bahwa media komik adalah suatu media atau alat atau sumber belajar yang berisikan gambar serta cerita yang menarik, serta disajikan dalam bentuk sederhana dengan bahasa verbal yang dialogis sehingga mudah dipahami siswa dan digemari oleh siswa yang dapat meningkatkan minat dan motivasi belajar siswa.

Selain komik dapat meningkatkan motivasi dan minat belajar siswa berdasarkan sifatsifat khas yang dimilikinya, komik juga memiliki kelebihan sebagai media pembelajaran yang dapat menguntungkan dalam dunia pendidikan atau dalam proses pembelajaran. Berikut beberapa kelebihan komik sebagai media pembelajaran, yaitu 1) sederhana dalam penyajiannya, 2) alur cerita berisi pesan atau informasi yang besar tetapi disajikan dengan ringkas sehingga mudah dipahami siswa, 3) berisi bahasa verbal yang dialogis, 4) terdapat perpaduan bahasa 
verbal dan non verbal, sehingga pembaca cepat memahami isi pesan atau informasi dari komik tersebut, 5) ekspresi yang divisualisasikan sehingga membuat pembaca terlibat secara emosional dan membuat pembaca ingin terus-menerus membacanya hingga selesai, 6) selain sebagai media pembelajaran dapat dimanfaatkan sebagai sumber belajar (Zulkifli, 2008).

Pada kesempatan kali ini peneliti membuat media pembelajaran komik dengan bantuan website "Toondo". Toondo adalah sebuah website online untuk membuat komik yang dapat diakses oleh semua kalangan, meskipun tanpa memiliki kemampuan menggambar yang baik sehingga mempermudah setiap orang agar dapat bisa membaut komik. Cama membuat komik dengan bantuan website online "Toondo", yaitu dengan mengakses link http://www.toondo.com kemudian dapat membuat akun secara gratis dan dapat memilih jenis komik yang hendak dibuat, dan dapat langsung membuat dengan memilih jenis subjek, objek yang disediakan dalam website tersebut, setelah selesai membuat komik dapat disimpat dan diunduh untuk disimpan atau langsung dicetak.

\section{SIMPULAN DAN SARAN}

\section{Simpulan}

Berdasarkan penelitian yang telah dilaksanakan dengan metode kuasi eksperimen (quasi experimental) dengan desain The Nonequivalent Posttest-Only Group Design, dan populasi dalam penelitian ini adalah siswa-siswi SDN Lebak Wangi, dengan Sampel yang diambil sebanyak dua kelas, yaitu kelas V-A sebagai kelas kontrol dan kelas V-B sebagai kelas eksperimen. Masing-masing kelas terdapat 33 siswa. Menunjukkan hasil yang dapat dinyatakan bahwa terdapat pengaruh penggunaan media komik untuk meningkatkan kemampuan koneksi matematis siswa di kelas V SDN Lebak Wangi pada materi kecepatan dan debit. Hal ini ditunjukkan dengan hasil hipotesis posstest yang mendapatkan nilai t sebesar 0,004 dengan taraf signifikansi 0,05. Selain itu nilai rata-rata posstest menunjukkan bahwa kelas eksperimen lebih tinggi dibandingkan kelas kontrol yakni sebesar 71,15 untuk kelas eksperimen dan 57,06 untuk kelas kontrol.

\section{Saran}

Berdasarkan hasil penelitian dan pengalaman yang telah diperoleh, peneliti dapat memberikan saran-saran. sebagai berikut 1) Guru dapat menggunakan media komik dalam pembelajaran matematika di sekolah sebagai media pembelajaran agar lebih menarik perhatian siswa, dan mampu meningkatkan kemampuan koneksi matematis siswa, 2) Pembuatan komik 
sebagai media haruslan sesuai dengan pokok bahasan yang akan dibahas, karena kesalaha dalam certa yang dibuat dalam komik akan mempengaruhi penyampaian konsep pembelajaran pada peserta didik, 3) Dengan adanya keterbatasan dalam melaksanakan penelitian ini, sebaiknya dapat dilakukan penelitian lanjutan bagi peneliti lainnya.

\section{DAFTAR PUSTAKA}

Arifin, F. Herman, T. The Influence Of E-Learning Model Web Enhanced Course To Conceptual Understanding And Self Regulated Learning in Mathematics for Elementary School Students. TARBIYA :Journal of Education in Muslim Society. 2017. Vol. 4 No. 1. doi:10.15408/tjems.v4i1.5536.

Arsyad, Azhar. Media Pembelajaran. Jakarta: Raja Grafindo Persada, 2004.

Atridayani, Amelinda. “Analisis Kemampuan Koneksi Matematis Peserta Didik Kelas VII SMPN 31 Semarang Pada Materi Perbandingan”. Skripsi padaUniversitas Islam Negri Walisongo.Semarang. 2017.

Fajriani. “Analisis Kemampuan Koneksi Matematis Siswa MTs An Najah Jakarta Selatan”. Skripsi pada Universitas Islam Negeri Syarif Hidayatullah. Jakarta; 2017.

Gazali, Rahmita Yuliana. Pembelajaran Matematika yang Bermakna. Jurnal Pendidikan Matematika, Vol. 2 No. 3, 2016.

Kemendikbud. "Peringkat dan Capaian PISA Indonesia Mengalami Peningkatan", http: www.kemendikbud.go.id, 06 Januari 2019.

Mulyawati, Novrike. Analisis Kemampuan Koneksi Matematis Siswa Tipe Kepribadian Rational dalam Menyelesaikan Soal Pada Materi Teorema Pythagoras dikelas VIII SMPN 5. Pendidikan Matematika FKIP Universitas Jambi, 2017.

Munadi, Yudhi. Media Pembelajaran. Jakarta: Gaung Persada Press, 2008.

NCTM. Principles and Standards for School Mathematics. Reston: NCTM, 2000.

Peraturan Pemerintah RI No. 47 tahun 2008 tentang. Wajib belajar pasal 1 ayat 2, Cet. Ke- 2. Bandung: Citra Umbara. 2009.

Ramdhani, Marlisa Rahmi, dkk. Analisis Kemampuan Koneksi Matematis Siswa Kelas VII SMPN 1 Kembaran Materi Bangun Datar. Seminar Nasional Matematika dan pendidikan matematika, 2016.

Shadiq, Fadjar, dkk. Penerapan Teori Belajar dalam Pembelajran Matematika di SD. Yogyakarta: Kemetrian Pendidikan Nasional, 2011. 
Siagian, Muhammad Daut. Kemampuan Koneksi Matematik Dalam Pembelajaran Matematika. MES (Jurnal of Mathematics Education and Science). Vol. 2 No. 1. 2016.

Tim Penyusun Kamus Bahasa Indonesia. Kamus Bahasa Indonesia. Jakarta: Pusat Bahasa Departemen Pendidikan Nasional, 2008.

Ulfah, Amaliyah. Komik Pembelajaran: Sebuah Media Untuk Membangun LIterasi Siswa Sekolah Dasar. PGSD Universitas Ahmad Dablan.

Undang-Undang Republik Indonesia No. 20 tahun 2003 tentang Sistem Pendidikan Nasional pasal 3 Cet. Ke-2. Bandung: Citra Umbara. 2009.

Waluyanto, Heru Dwi. Komik Sebagai Media Komunikasi Visual Pembelajaran. Jurnal Nirmana, Vol. 7, No. 1, 2005. 